\title{
Effectiveness of the serious game for learning in nursing: systematic review
}

\author{
Efetividade do serious game para a aprendizagem na enfermagem: revisão sistemática \\ Eficacia del juego serio para el aprendizaje en enfermería: revisión sistemática
}

\author{
Kleiton Gonçalves do Nascimento ${ }^{a}$ \\ Maria Beatriz Guimarães Ferreira ${ }^{a, b}$ \\ Márcia Marques dos Santos Felix ${ }^{a}$ \\ Juliana da Silva Garcia Nascimentoc \\ Suzel Regina Ribeiro Chavaglia ${ }^{d}$ \\ Maria Helena Barbosad
}

\section{How to cite this article:}

Nascimento KG, Ferreira MBG, Felix MMS, Nascimento ISG, Chavaglia SRR, Barbosa MH. Effectiveness of the serious game for learning in nursing: systematic review. Rev Gaúcha Enferm. 2021;42:e20200274. doi: https://doi.org/10.1590/19831447.2021.20200274
Universidade Federal do Triângulo Mineiro (UFTM) Instituto de Ciências da Saúde, Programa de PósGraduação stricto sensu em Atenção à Saúde. Uberaba, Minas Gerais, Brasil.

buniversidade Federal de Uberlândia (UFU), Faculdade de Medicina, Curso de Graduação em Enfermagem. Uberlândia, Minas Gerais, Brasil.

' Universidade de São Paulo (USP), Escola de Enfermagem de Ribeirão Preto, Programa de Pós Graduação em Enfermagem Fundamental. Ribeirão Preto, São Paulo, Brasil.

d Universidade Federal do Triângulo Mineiro (UFTM), Instituto de Ciências da Saúde. Departamento Didático-Científico de Enfermagem na Assistência Hospitalar. Uberaba, Minas Gerais, Brasil.

\section{ABSTRACT}

Objective: To identify the effectiveness of the serious game in improving learning outcomes compared to the different teaching strategies used in the education of nursing students.

Method: Systematic review, conducted from July 2019 to May 2020, at PubMed ${ }^{\oplus}$, Scopus, CINAHL, Web of Science and LILACS. Studies of experimental and quasi-experimental design were included, with no delimitation of time frame, aimed at nursing students, who approached the use of the serious game as the main teaching strategy compared with other pedagogical methods.

Results: Six articles were included, which compared the serious game with traditional and active teaching and learning strategies (expository class, text reading and simulation). The studies were considered of moderate quality, with an average score of 12.83 . Nursing students submitted to the serious game showed better learning results.

Conclusion: The serious game proved to be more effective for learning in nursing when compared to other teaching strategies. Keywords: Students, nursing. Knowledge. Teaching. Video games.

\section{RESUMO}

Objetivo: Identificar a eficácia do serious game na melhoria dos resultados de aprendizagem em comparação às diferentes estratégias de ensino utilizadas na educação de estudantes de enfermagem.

Método: Revisão sistemática, realizada de julho/2019 a maio/2020, na PubMed', Scopus, CINAHL, Web of Science e LILACS. Incluíram-se estudos de delineamento experimental e quasi-experimental, sem delimitação de recorte temporal, voltados a estudantes de enfermagem, que abordassem o uso do serious game como principal estratégia de ensino comparada com outros métodos pedagógicos.

Resultados: Foram incluídos seis artigos, os quais compararam o serious game com estratégias tradicionais e ativas de ensino e aprendizagem (aula expositiva, leitura de textos e simulação). Os estudos foram considerados de qualidade moderada, com escore médio de 12,83. Os estudantes de enfermagem submetidos ao serious game apresentaram melhores resultados de aprendizagem.

Conclusão: 0 serious game demonstrou-se mais efetivo para aprendizagem em enfermagem quando comparado a outras estratégias de ensino.

Palavras-chave: Estudantes de enfermagem. Conhecimento. Ensino. Jogos de vídeo.

\section{RESUMEN}

Objetivo: Identificar la efectividad del juego serio em la mejora de los resultados del aprendizaje en comparación con las diferentes estrategias de enseñanza utilizadas en la educación de los estudiantes de enfermería.

Métodos: Revisión sistemática, realizada de julio de 2019 a mayo de 2020, en PubMed', Scopus, CINAHL, Web of Science y LILACS. Se incluyeron estudios de diseño experimental y cuasiexperimental, sin delimitación temporal, dirigidos a estudiantes de enfermería, quienes abordaron el uso del juego serio como principal estrategia de enseñanza frente a otros métodos pedagógicos.

Resultados: Se incluyeron seis artículos, que compararon el juego serio con estrategias de enseñanza y aprendizaje tradicionales y activas (clase expositiva, lectura de textos y simulación). Los estudios se consideraron de calidad moderada, con una puntuación media de 12,83. Los estudiantes de enfermería sometidos al juego serio mostraron mejores resultados de aprendizaje.

Conclusión: El juego serio demostró ser más efectivo para aprendizaje en enfermería en comparación con otras estrategias de enseñanza.

Palabras clave: Estudiantes de enfermería. Conocimiento. Enseñanza. Juegos de video. 


\section{口INTRODUCTION}

The changes in the current educational scenario affect Higher Education in a notorious way, requiring the rupture of traditional pedagogical barriers ${ }^{(1-4)}$. In this perspective, virtual simulation, characterized as a teaching and learning strategy that replicates real clinical situations, developed in a digital learning environment, presents itself as a valuable pedagogical, technological and innovative resource ${ }^{(5)}$.

Despite the imposed difficulties, often, due to the lack of technological resources, nursing schools try to change their paradigms about integrating technology and teaching ${ }^{(6)}$ based on digital strategies, such as virtual simulation, made possible, usually by the serious game ${ }^{(7)}$.

Serious game is defined as an educational game, based on computer technology with gameplay aspects, accessed by computer or smartphone, which stands out when compared to other media, as it allows the challenge and the player's involvement during the interaction, besides to be based on logical and emotional responses, which allow the user to better integrate with technology and change the course of actions demonstrated in the multimedia resource ${ }^{(8-9)}$.

Considered a type of virtual simulation for its ability to create realistic environments so that students can act and build their learning, simulating the execution of certain care, as many times as necessary, in a virtual environment, in order to improve their technical and managerial skills, the serious game is still little explored for nursing education ${ }^{(10)}$.

The literature points out to studies with the application of the serious game in different contexts, for example, to teach nursing students about the patients' care with chronic obstructive pulmonary disease at home and in health services ${ }^{(8)}$, or in the context of neonatal resuscitation, adopted by nursing students and professionals $s^{(11)}$.

Despite the potentiality of this educational technology to provide nursing students' learning, there is a lack of clarity to affirm that this strategy is superior to other teaching techniques to develop cognitive skill in undergraduates( ${ }^{(9)}$, which instigates the need to evaluate the methodological quality of scientific research in this area and to identify whether the serious game has been pointed out as effective for learning in nursing, when compared to other pedagogical strategies ${ }^{(12)}$. The objective of this review was to identify the effectiveness of the serious game in improving learning outcomes compared to the different teaching strategies used in the education of nursing students.

\section{METHODS}

This is a systematic literature review, carried out using the strategy Preferred Reporting Items for Systematic Reviews and Meta-Analysis (PRISMA)(13), from June 2019 to May 2020, registered in the International Prospective Register of Systematic Reviews (PROSPERO)(14) under number 153102.

For its elaboration, seven stages were taken, namely: definition of the research question; identification of databases, descriptors, keywords and search strategies; establishment of inclusion and exclusion criteria; database searches; comparison of examiners'searches and definition of initial study selection; critical analysis of all studies included in the review and preparation of a critical summary ${ }^{(15)}$.

The research question was defined through the PICO strategy (acronym for Patient-Intervention-Comparison-Outcomes) ${ }^{(16)}$, to describe the following elements: P (population) for undergraduate nursing students; I (intervention) for using serious game; $\mathrm{C}$ (comparison) for different teaching strategies and $\mathrm{O}$ (outcome) for improvement in learning outcomes. Thus, the question was structured: How effective is the serious game in comparison with different teaching-learning strategies in improving the learning outcomes of nursing students?

Primary studies were included, such as clinical trial, randomized or not, controlled or not, and which presented the comparison of the effectiveness of the serious game with different types of teaching-learning strategies, in order to obtain better results in the learning of nursing students; published in Portuguese, English and Spanish; in scientific journals and without delimited time frame. Case studies, literature reviews, editorials, reviews, case reports and experiences reports, theoretical reflections, dissertations, theses, monographs, and abstracts published in event overviews were excluded.

The searches were performed in the PubMed ${ }^{\circ}$, Scopus e Web of Science virtual libraries and in the Latin American and Caribbean Health Sciences (Literatura Latino-Americana e do Caribe em Ciências da Saúde - LILACS) and Cumulative Index to Nursing and Allied Health Literature (CINAHL) databases. Cross-reference searches were also performed. For search, it was used controlled descriptors and the Boolean operators AND, for simultaneous occurrence of subjects, and OR, for occurrence of one or the other subject. The terms used were identified in the Medical Subjects Headings (MeSH) and/or in the Health Sciences Descriptors (Descritores em Ciências da Saúde - DeCS). The term Serious Game was used as a keyword to direct the search strategy, given the specificity of the theme. The search strategies are presented in chart 1. 


\begin{tabular}{|c|c|}
\hline $\begin{array}{l}\text { Libraries and } \\
\text { databases }\end{array}$ & Search strategy \\
\hline $\begin{array}{l}\text { PubMed } \\
\text { and Scopus }\end{array}$ & 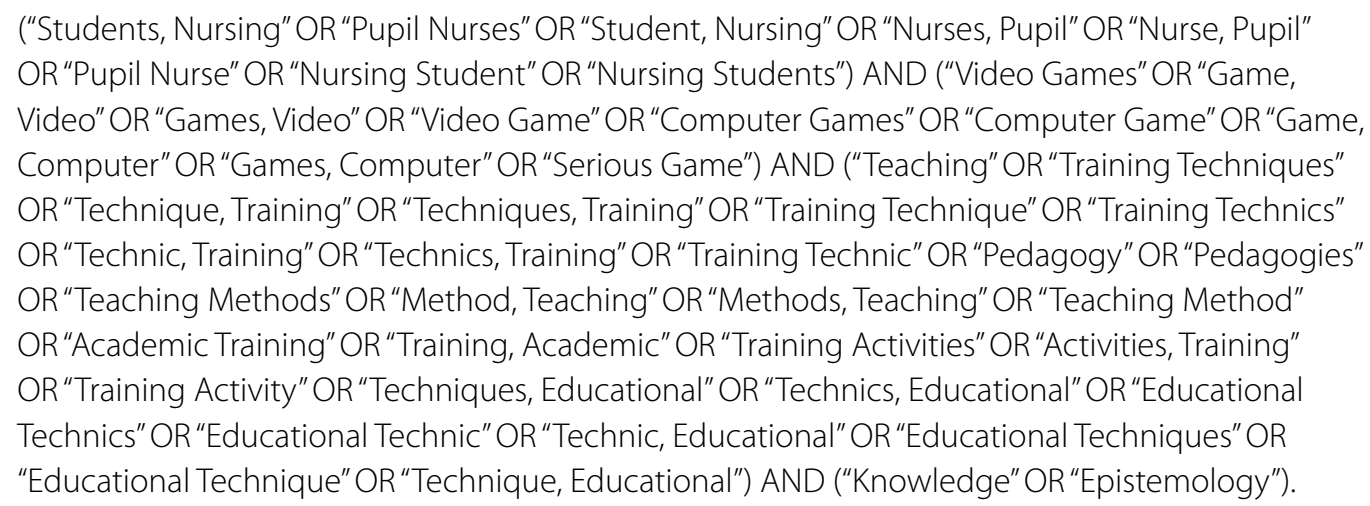 \\
\hline CINAHL & $\begin{array}{l}\text { ("Students, Nursing" OR"Nursing Student" OR "Nursing Students" OR "Student Nurses" OR "Student, } \\
\text { Nursing") AND ("Video Games" OR "Game, Video"OR "Games, Video" OR"Video Game" OR Serious } \\
\text { Game) AND ("Teaching Methods") AND (Knowledge OR "Health Knowledge"). }\end{array}$ \\
\hline Web of Science & (Students, Nursing AND Video Games OR Serious Game AND Teaching AND Knowledge). \\
\hline LILACS & $\begin{array}{l}\text { ("Estudantes de Enfermagem" AND "Jogos de Vídeo" AND "Serious Game" AND "Educação em } \\
\text { Enfermagem" AND Conhecimento); ("Students, Nursing" AND "Video Games" AND "Serious Games" } \\
\text { AND "Education, Nursing" AND Knowledge); ("Estudiantes de Enfermería" AND"Juegos de Video" AND } \\
\text { "Serious Game" AND "Educación en Enfermería" OR "Educação em Enfermagem AND Conocimiento). }\end{array}$ \\
\hline
\end{tabular}

Chart 1 - Search strategies used in the databases selected for the study

Source: Authors, 2020.

CINAHL: Cumulative Index to Nursing and Allied Health Literature; LILACS: Latin American and Caribbean Literature in Health Sciences (Literatura Latino-Americana e do Caribe em Ciências da Saúde).

The search in databases and virtual libraries was carried out by two independent researchers, first evaluating titles and abstracts, through the review application Rayyan QCRI, a program that streamlines the initial screening of studies, through a semi automation process that guarantees the selection reliability ${ }^{(17)}$. Afterwards, 16 studies that showed divergence were sent to a third researcher, responsible for making the inclusion or exclusion decision. Then, the articles were read and fully critically analyzed, to define the final sample.

The methodological evaluation of the selected studies was carried out, according to the Medical Education Research Study Quality Instrument (MERSQI)(18). The MERSQI allows to assess the methodological rigor of the articles and consists by six domains: study design, with a single group and a posttest (1 point), single group pre-test and post-test (1.5 points), two groups non-randomized (2 points) and randomized study (3 points); sampling with one institution ( 0.5 point), two institutions (1 point), three institutions (1.5 point) and sampling response rate $<50 \%$ (- 0.5 point), from $50 \%$ to $74 \%$ ( 1 point) and $>75 \%$ (1.5 points); type of assessment, if done by participants (1 point) and objective assessment ( 2 points); instrument validity, if internal structure not reported (zero point), reported (1 point), not reported content (zero point), reported content (1 point), relationships to other not reported variables (zero point) and reported relationships (1 Score); data analysis, if inappropriate for study design (zero point), appropriate for the study design (1 point), descriptive analysis (1 point), beyond descriptive analysis (2 points) and outcomes, if knowledge and skills (1.5 points) and satisfaction, attitudes, perceptions, opinions, general facts and confidence (1 point). The maximum score is $18^{(19)}$. 
Studies with scores $\leq 10$ are considered of low quality; from $>10$ to $<15$, of moderate quality; and $\geq 15$, high quality ${ }^{(20)}$.

The data were synthesized in a descriptive way, extracting the following criteria present in an already validated instrument ${ }^{(19)}$, namely: research title, authors, learning objectives of the serious game and type of skill developed by the student, intervention, outcomes and recommendations/ conclusion.

To present the studies selection path, it was used the flowchart proposed by the recommendations of the Preferred Reporting Items for Systematic Reviews and Meta Analyses (PRISMA) $^{(13)}$ (Figure 1).

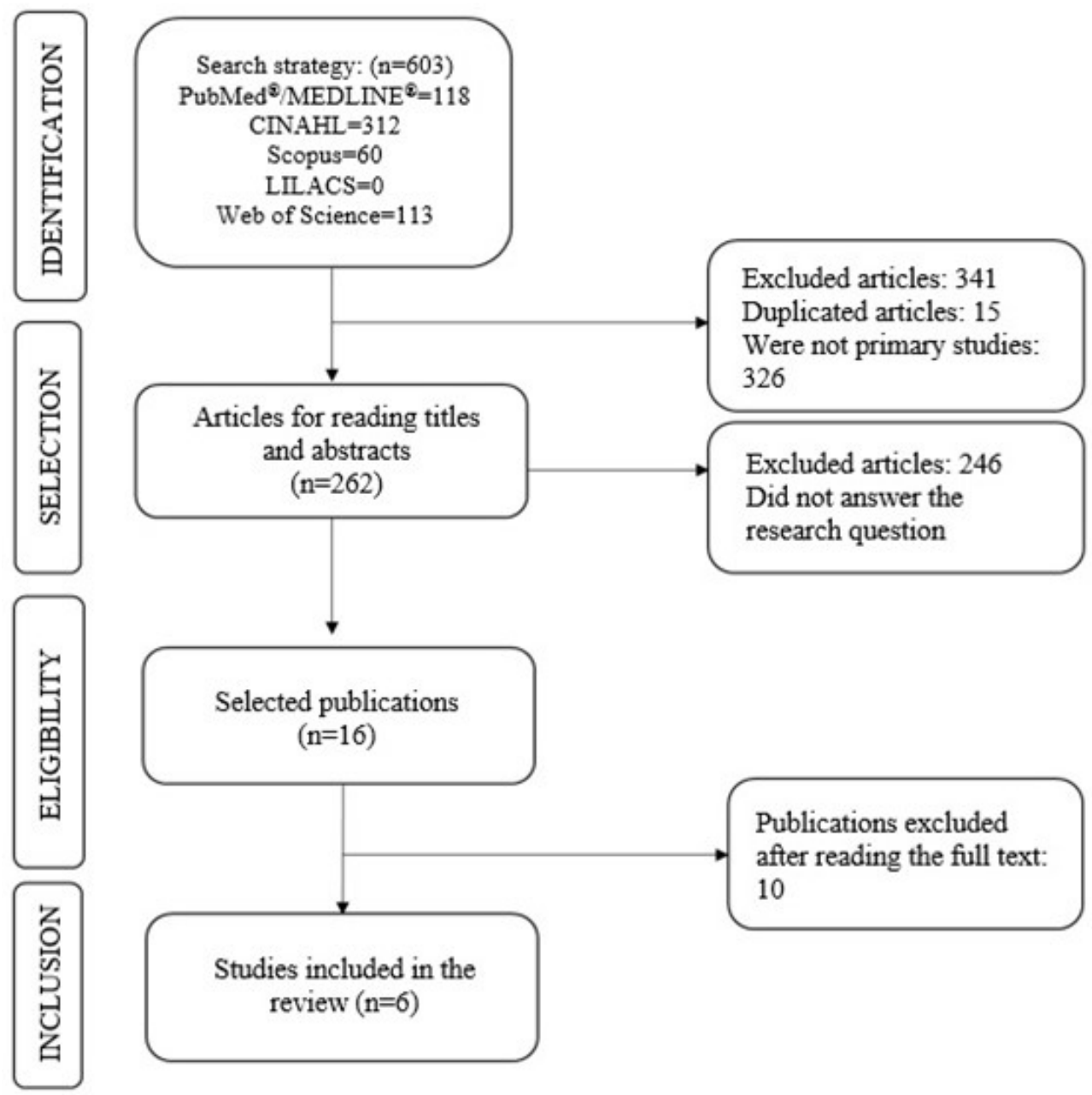

Figure 1 - Flowchart of the process of identification, selection and inclusion of studies Source: Authors, based on Moher et al.!(13).

\section{RESULTS}

Six primary studies were selected to compose the sample of the present research, from which it was extracted the research title; authors; serious game learning objectives; type of skill developed in the nursing student - considering cognitive (knowledge), psychomotor (procedural) and affective (attitudes) skills; intervention, outcomes, and conclusion, contemplated in the synoptic chart (Chart 2).

The studies were mostly international and of experimental design ${ }^{(22-26)}$, published in the last 5 years, with the exception of one, published in $2012^{(26)}$, and with sampling variability from 14 to 109 individuals. The language adopted by most articles was English ${ }^{(22-26)}$ and the simulations performed using the serious game presented online $e^{(21,24,26)}$ and presential formats ${ }^{(22-23,25)}$.

The serious game learning objectives were mostly focused on the knowledge, understanding and application of nursing $\operatorname{care}^{(21-24,26)}$. The main skills developed by nursing students, submitted to the serious game were cognitive skills (knowledge in nursing) ${ }^{(21-26)}$ and psychomotor skills (procedural) (22-24,26). Affective skills (attitudes and feelings) were valued by three studies ${ }^{(21-22,25)}$, considering the development of satisfaction and confidence. 


\begin{tabular}{|c|c|c|c|}
\hline Authors and title & $\begin{array}{l}\text { Serious game learning } \\
\text { objectives and skills } \\
\text { developed by nursing } \\
\text { students }\end{array}$ & Intervention & $\begin{array}{l}\text { Outcomes and } \\
\text { recommendations/ } \\
\text { conclusion }\end{array}$ \\
\hline $\begin{array}{l}\text { Fonseca et al. }{ }^{(21)} \\
\text { Computer and } \\
\text { laboratory } \\
\text { simulation in } \\
\text { the teaching of } \\
\text { neonatal nursing: } \\
\text { Innovation and } \\
\text { impact on learning. }\end{array}$ & $\begin{array}{l}\text { To understand the clinical } \\
\text { evaluation of oxygenation } \\
\text { of preterm newborns in } \\
\text { the Neonatal Intensive } \\
\text { Care Unit. } \\
\text { Skills: cognitive (knowledge) } \\
\text { and affective } \\
\text { (satisfaction). }\end{array}$ & $\begin{array}{l}\text { Quasi-experimental } \\
\text { study with } 14 \text { students. } \\
\text { Intervention: use of } \\
\text { Serious game e-Baby. The } \\
\text { experimental group ( } \mathrm{n}=7 \text { ) } \\
\text { was submitted to the serious } \\
\text { game; the control group } \\
\text { ( } \mathrm{n}=7 \text { ) was submitted to } \\
\text { laboratory simulation. }\end{array}$ & $\begin{array}{l}\text { The serious game showed } \\
\text { a statistically significant } \\
\text { difference ( } \mathrm{p}=0.001) \text { in } \\
\text { cognitive skill. The students } \\
\text { were satisfied with the game. } \\
\text { There was an improvement in } \\
\text { knowledge and satisfaction. } \\
\text { The nursing serious game } \\
\text { is recommended. }\end{array}$ \\
\hline $\begin{array}{l}\text { Tan et al. }{ }^{(22)} \\
\text { Designing and } \\
\text { evaluating the } \\
\text { effectiveness } \\
\text { of a serious } \\
\text { game for safe } \\
\text { administration of } \\
\text { blood transfusion: } \\
\text { A randomized } \\
\text { controlled trial. }\end{array}$ & $\begin{array}{l}\text { To know and apply the } \\
\text { blood transfusion procedure } \\
\text { and the specific care given } \\
\text { to the transfusion reaction. } \\
\text { Skills: cognitive (knowledge), } \\
\text { psychomotor, (procedural) } \\
\text { and affective } \\
\text { (confidence). }\end{array}$ & $\begin{array}{l}\text { Randomized experimental } \\
\text { study with } 103 \text { students. } \\
\text { Intervention: use of a serious } \\
\text { game on blood transfusion. } \\
\text { The experimental group } \\
\text { ( } n=57 \text { ) performed the } \\
\text { serious game associated } \\
\text { with lectures; the control } \\
\text { group ( } n=46 \text { ) was submitted } \\
\text { to lectures. }\end{array}$ & $\begin{array}{l}\text { There was a significant } \\
\text { improvement ( } p<0.001) \\
\text { in the knowledge of the } \\
\text { experimental group, high } \\
\text { psychomotor performance, } \\
\text { however without statistical } \\
\text { significance and development } \\
\text { of confidence. It is } \\
\text { recommended to adopt the } \\
\text { serious game to develop } \\
\text { cognitive, psychomotor, and } \\
\text { affective skills in nursing. }\end{array}$ \\
\hline $\begin{array}{l}\text { Bayram et al. }{ }^{(23)} \\
\text { Effect of a game- } \\
\text { based virtual reality } \\
\text { phone application } \\
\text { on tracheostomy } \\
\text { care education for } \\
\text { nursing students: } \\
\text { A randomized } \\
\text { controlled trial. }\end{array}$ & $\begin{array}{l}\text { To know and apply nursing } \\
\text { care for tracheostomized } \\
\text { patients. Skills: cognitive } \\
\text { (knowledge) and } \\
\text { psychomotor } \\
\text { (procedural). }\end{array}$ & $\begin{array}{l}\text { Experimental, randomized } \\
\text { study with } 86 \text { students. } \\
\text { Intervention: serious game } \\
\text { about tracheostomy care. The } \\
\text { experimental group ( } \mathrm{n}=43 \text { ) } \\
\text { was submitted to serious } \\
\text { game, expository classes } \\
\text { and laboratory training. } \\
\text { The control group ( } \mathrm{n}=43 \text { ) } \\
\text { to expository class and } \\
\text { laboratory training. }\end{array}$ & $\begin{array}{l}\text { There was no statistically } \\
\text { significant difference for } \\
\text { knowledge between the } \\
\text { groups ( } p>0.05 \text { ), however, } \\
\text { the scores of psychomotor } \\
\text { skills were higher for } \\
\text { the experimental group } \\
\text { ( } p=0.017) \text {. The serious game } \\
\text { is recommended for learning } \\
\text { in nursing. }\end{array}$ \\
\hline
\end{tabular}

Chart 2 - Description of the characteristics of the included studies. Uberaba, Minas Gerais, 2020 


\begin{tabular}{|c|c|c|c|}
\hline Authors and title & $\begin{array}{l}\text { Serious game learning } \\
\text { objectives and skills } \\
\text { developed by nursing } \\
\text { students }\end{array}$ & Intervention & $\begin{array}{l}\text { Outcomes and } \\
\text { recommendations/ } \\
\text { conclusion }\end{array}$ \\
\hline $\begin{array}{l}\text { Boada et al. }{ }^{(24)} \\
\text { Using a serious } \\
\text { game to } \\
\text { complement CPR } \\
\text { instruction in a } \\
\text { nurse faculty. }\end{array}$ & $\begin{array}{l}\text { To know and apply the } \\
\text { care of a cardiorespiratory } \\
\text { arrest by means of } \\
\text { cardiopulmonary } \\
\text { resuscitation. } \\
\text { Skills: cognitive } \\
\text { (knowledge) and } \\
\text { psychomotor } \\
\text { (procedural). }\end{array}$ & $\begin{array}{l}\text { Experimental, randomized } \\
\text { study with } 109 \text { students. } \\
\text { Intervention: LISSA } \\
\text { serious game for teaching } \\
\text { cardiorespiratory arrest. } \\
\text { The experimental group } \\
\text { (n=67) performed the } \\
\text { serious game, expository } \\
\text { class and laboratory } \\
\text { training. The control group } \\
\text { (n=42) expository class and } \\
\text { laboratory training. }\end{array}$ & $\begin{array}{l}\text { The experimental group } \\
\text { obtained significantly better } \\
\text { knowledge scores ( } \mathrm{p}<0.05 \text { ) } \\
\text { than the control group. The } \\
\text { intervention group also } \\
\text { showed improvement in } \\
\text { psychomotor skills. The use } \\
\text { of LISSA improves students' } \\
\text { knowledge and skills in CPR. }\end{array}$ \\
\hline $\begin{array}{l}\text { Aljezawi et al. }{ }^{(25)} \\
\text { Quiz game } \\
\text { teaching } \\
\text { format versus } \\
\text { didactic lectures }\end{array}$ & $\begin{array}{l}\text { To understand the patient } \\
\text { care organization models, } \\
\text { including nursing care, } \\
\text { teamwork, primary nursing } \\
\text { care and case management. } \\
\text { Skills: cognitive (knowledge) } \\
\text { and affective } \\
\text { (satisfaction) }\end{array}$ & $\begin{array}{l}\text { Experimental, randomized } \\
\text { study with } 66 \text { students. } \\
\text { Intervention: use of the } \\
\text { serious game. Experimental } \\
\text { group ( } n=34 \text { ) submitted to } \\
\text { the serious game. Control } \\
\text { group ( } n=32 \text { ) expository class. }\end{array}$ & $\begin{array}{l}\text { The students submitted to the } \\
\text { game had significantly higher } \\
\text { scores for knowledge (control } \\
\text { group: } 9.63 \pm 1.79 ; \text { experimental } \\
\text { group } 11.34 \pm 2.17 ; p<0.001 \text { ), } \\
\text { and their retention (control } \\
\text { group: } 7.10 \pm 1.49 ; \text { experimental } \\
\text { group: } 9.00 \pm 2.08 ; p<0.001 \text { ). } \\
\text { There was a statistically } \\
\text { significant difference in the } \\
\text { satisfaction of the intervention } \\
\text { group ( } p<0.001 \text { ). It is } \\
\text { recommended to adopt the } \\
\text { serious game for teaching. }\end{array}$ \\
\hline $\begin{array}{l}\text { LeFlore et al. } \\
\text { Can a virtual } \\
\text { patient trainer } \\
\text { teach student } \\
\text { nurses how to save } \\
\text { lives--teaching } \\
\text { nursing students } \\
\text { about pediatric } \\
\text { respiratory diseases }\end{array}$ & $\begin{array}{l}\text { To know the different signs } \\
\text { and symptoms associated } \\
\text { with pediatric respiratory } \\
\text { diseases and the best care. } \\
\text { Skills: cognitive (knowledge) } \\
\text { and psychomotor } \\
\text { (procedural) }\end{array}$ & $\begin{array}{l}\text { Experimental, randomized } \\
\text { study with } 93 \text { students. } \\
\text { Intervention: serious game } \\
\text { on pediatric ventilation. The } \\
\text { experimental group ( } \mathrm{n}=46 \text { ) } \\
\text { was submitted to serious } \\
\text { game, reading and simulation } \\
\text { in the laboratory. The control } \\
\text { group ( } \mathrm{n}=47 \text { ) the lecture and } \\
\text { simulation in the laboratory. }\end{array}$ & $\begin{array}{l}\text { There was a significant } \\
\text { difference in knowledge } \\
\text { between the control and } \\
\text { experimental groups (mean } \\
\text { score } 75 \pm 12 \text { versus } 83.9 \pm 15 \text {, } \\
\text { respectively, } p=0.004 \text { ). The } \\
\text { experimental group performed } \\
\text { better in the tasks ( } p=0.001 \text { ). } \\
\text { It is concluded that the game } \\
\text { can be effective for learning } \\
\text { in nursing. }\end{array}$ \\
\hline
\end{tabular}

Chart 2 - Cont. Source: Authors, 2020. 
The interventions used in the selected studies were specific serious game formats, with themes addressed to adult patients in severe condition in four articles ${ }^{(22-25)}$, neonatal patient in one study ${ }^{(21)}$ and another with pediatric patient ${ }^{(26)}$, compared with traditional strategies, such as: the expository class and/or lectures, text reading and skills training in the laboratory ${ }^{(21-25)}$, and with the active strategy of clinical simulation, performed in the laboratory ${ }^{(26)}$. From these different teaching strategies, used to compare the effectiveness of learning with the serious game, the most adopted was the dialogue expository class ${ }^{(23-25)}$.

It was performed a critical methodological evaluation of the selected studies for the present review using the MERSQI instrument ${ }^{(18)}$ (Chart 3).
The critical methodological evaluation of the articles carried out using MERSQI(18) revealed moderate quality for the selected study sample, with an mean score of 12.83, a minimum of 11 and a maximum of 14.5 points. The main methodological fragility identified by MERSQI were: in the "sample" domain, specifically regarding the item "center", due to the performance of studies in a single center ${ }^{(21-26)}$; in the "validity of the assessment instrument" domain, due to the lack of description of the validity of the instruments used for learning ${ }^{(21,24)}$ and, in the "outcomes" domain, due to the valorization of the development of knowledge and psychomotor skills, to the detriment of the skills affective (attitudes/feelings) in nursing students ${ }^{(23,26)}$, and the lack of evaluation of the change in student behavior and the intended outcome in patients ${ }^{(21-26)}$.

\begin{tabular}{|c|c|c|c|c|c|c|}
\hline \multirow[b]{2}{*}{ Domains } & \multicolumn{6}{|c|}{ References } \\
\hline & $\begin{array}{l}\text { Fonseca } \\
\text { et al. }{ }^{(21)}\end{array}$ & Tan et al. ${ }^{(22)}$ & $\begin{array}{l}\text { Bayram } \\
\text { et al. } \text {.23) }^{2}\end{array}$ & $\begin{array}{l}\text { Boada } \\
\text { et al. } .^{(24)}\end{array}$ & $\begin{array}{l}\text { Aljezawi } \\
\text { et al. }{ }^{(25)}\end{array}$ & $\begin{array}{l}\text { Leflore } \\
\text { et al. }{ }^{(26)}\end{array}$ \\
\hline Study design & $\begin{array}{c}\text { Non-randomized: } \\
2\end{array}$ & $\begin{array}{c}\text { Randomized: } \\
3\end{array}$ & $\begin{array}{c}\text { Randomized: } \\
3\end{array}$ & $\begin{array}{c}\text { Randomized: } \\
3\end{array}$ & $\begin{array}{c}\text { Randomized: } \\
3\end{array}$ & $\begin{array}{c}\text { Randomized: } \\
3\end{array}$ \\
\hline $\begin{array}{l}\text { Sampling: center } \\
\text { and response rate }\end{array}$ & $\begin{array}{c}\text { One } \\
\text { institution: } 0.5 \\
\text { 50\%-74\% rate: } 1\end{array}$ & $\begin{array}{c}\text { One } \\
\text { institution: } \\
0.5 \text { and }>75 \% \\
\text { rate: } 1.5\end{array}$ & $\begin{array}{c}\text { One } \\
\text { institution: } 0.5 \\
\text { and } 50 \%-74 \% \\
\text { rate: } 1\end{array}$ & $\begin{array}{c}\text { One } \\
\text { institution:0,5 } \\
\text { and }>75 \% \\
\text { rate: } 1.5\end{array}$ & $\begin{array}{c}\text { One } \\
\text { institution: } \\
0.5 \text { and }>75 \% \\
\text { rate: } 1.5\end{array}$ & $\begin{array}{c}\text { One } \\
\text { institution: } \\
0.5 \text { and }>75 \% \\
\text { rate: } 1.5\end{array}$ \\
\hline $\begin{array}{l}\text { Type } \\
\text { of assessment }\end{array}$ & Objective: 2 & Objective: 2 & Objective: 2 & Objective: 2 & Objective: 2 & Objective: 2 \\
\hline $\begin{array}{l}\text { Instrument } \\
\text { validity }\end{array}$ & Not reported: 0 & $\begin{array}{l}\text { Internal } \\
\text { structure:1 } \\
\text { Content: } 1\end{array}$ & $\begin{array}{l}\text { Internal } \\
\text { structure:1 } \\
\text { Content: } 1\end{array}$ & $\begin{array}{c}\text { Not } \\
\text { reported: } 0\end{array}$ & Content: 1 & Content: 1 \\
\hline Data analysis & $\begin{array}{l}\text { Appropriate:1 } \\
\text { Beyond } \\
\text { descriptive } \\
\text { analysis: } 2\end{array}$ & $\begin{array}{l}\text { Appropriate:1 } \\
\text { Beyond } \\
\text { descriptive } \\
\text { analysis: } 2\end{array}$ & $\begin{array}{l}\text { Appropriate:1 } \\
\text { Beyond } \\
\text { descriptive } \\
\text { analysis: } 2\end{array}$ & $\begin{array}{c}\text { Appropriate:1 } \\
\text { Beyond } \\
\text { descriptive } \\
\text { analysis: } 2\end{array}$ & $\begin{array}{l}\text { Appropriate:1 } \\
\text { Beyond } \\
\text { descriptive } \\
\text { analysis: } 2\end{array}$ & $\begin{array}{c}\text { Appropriate:1 } \\
\text { Beyond } \\
\text { descriptive } \\
\text { analysis: } 2\end{array}$ \\
\hline Outcomes & $\begin{array}{l}\text { Knowledge and } \\
\text { skill: } 1.5 \\
\text { Affective skills: } 1\end{array}$ & $\begin{array}{l}\text { Knowledge } \\
\text { and skill:1,5 } \\
\text { Affective } \\
\text { skills: } 1\end{array}$ & $\begin{array}{l}\text { Knowledges } \\
\text { and skills: } 1.5\end{array}$ & $\begin{array}{l}\text { Knowledge } \\
\text { and skill: } 1.5 \\
\text { Affective } \\
\text { skills: } 1\end{array}$ & $\begin{array}{l}\text { Knowledge } \\
\text { and skill: } 1.5 \\
\text { Affective } \\
\text { skills: } 1\end{array}$ & $\begin{array}{l}\text { Knowledges } \\
\text { and skills: } 1.5\end{array}$ \\
\hline Total Score & 11 & 14.5 & 13 & 12.5 & 13.5 & 12.5 \\
\hline
\end{tabular}

Chart 3 - Critical methodological evaluation of the studies that comprised the sample of the present systematic review, through the Medical Education Research Study Quality Instrument. Uberaba, Minas Gerais, 2020.

Source: Authors, 2020. 


\section{DISCUSSION}

The studies identified in the scientific literature regarding the effectiveness of the serious game, composed a sample of six articles, considered incipient, since this strategy is expanding in nursing education ${ }^{(22,25-27)}$.

It becomes necessary to evaluate the cost-benefit issue to develop a serious game ${ }^{(21)}$, because, despite its construction being considered, often costly, its potentialities characterized, mainly, by offering experiences in a safe environment, an active and meaningful learning, support for training, with solid concepts, based on critical thinking, problem solving, planning and adaptability ${ }^{(21)}$, can overcome the difficulties, since the learning results from clinical simulation in the laboratory do not always obtain significant difference in terms of skill development, and maintaining this physical environment, can outweigh the costs of a serious game ${ }^{(21-22,26-27)}$.

The safe environment for learning generated by the serious game is due to the option that the student has to perform the same procedure repeatedly, allowing errors to improve the techniques, since the virtual aspect does not expose the patient or impairs his safety ${ }^{(10)}$. This environment is capable of enabling simulations in online format, in which nursing students are submitted to the game on a digital platform, without the presence of a facilitator ${ }^{(21,24,26)}$ and in person, made possible in laboratories, with the facilitation of one teacher, to monitoring and carry out debriefing ${ }^{(22-23,25)}$. However, one of the trends of greater educational impact in the short term, for the serious game, is the growing focus on the use of combined models of classroom-based and online learning ${ }^{(28)}$.

The use of combined formats of learning for the serious game is a strong trend as online teaching is seen as a supplement to face-to-face learning, given its flexibility, ease of access, as well as integration between technologies and sophisticated multimedia. The combination of both formats enhances the creation of knowledge and, consequently, the increase in student performance levels ${ }^{(28)}$.

Most of the studies selected in the sample of the present research ${ }^{(21-22,24-26)}$ indicated that the serious game is a more effective pedagogical tool when compared to traditional teaching strategies, such as lectures, text reading, laboratory skills training and expository class, configured as the most commonly used strategy. The clinical simulation performed in the laboratory, as an active teaching strategy, was addressed by only one study ${ }^{(26)}$, therefore, more research is needed to support the comparison of its effectiveness with the serious game.

It is also important to consider that, although the serious game has proved effective for learning in nursing, this statement is not yet capable of sustaining its exclusive adoption for the teaching process, suggesting the articulation of the serious game with other didactic tools $s^{(1)}$.

A systematic review about the serious game in health showed that, despite its expansion in teaching, there is still a need to create well-grounded theories, capable of exploring the experience, the psychological effects of the mechanisms of games on students and their potential to develop knowledge in nursing and support the teaching and learning process in this context(29). Thus, it is essential to substantiate the development of the serious game, a priori, establishing its learning objectives in Bloom's Taxonomy, a reference that enables the structuring, organization, and definition of objectives to achieve better educational results through the serious game, and also in a meaningful and experiential learning framework, which sustains its path and enables the apprentice's evaluation ${ }^{(30)}$.

The practical use of the serious game depends on the quality of the evidence on its effectiveness and also on the support evidenced by the methodological quality of the studies that address this theme ${ }^{(1,29-31)}$. In the present study, the methodological quality was assessed as moderate, which is similar to other studies ${ }^{(1,31-32)}$. The moderate quality was possibly due to the existence of certain weaknesses contained in the methodological path of the studies - among them the performance of studies in only a single center.

The importance of developing multicenter research that addresses the adoption of the serious game as a pedagogical strategy for best practices is given by obtaining larger samples for more generalizable discoveries and by sharing resources between collaborative sites and promoting networks, in addition to well-executed multicenter studies have more chances to improve the researcher's performance and promote a positive impact on patient results ${ }^{(31)}$.

Another aspect highlighted by MERSQI was the absence of a description of the instruments'validation used to assess nursing learning through the serious game ${ }^{(21,24)}$. The validation process of an instrument adopted in scientific research is an essential step to maintain its reliability and collaborates to confirm that the instrument constitutes a universe of items that clearly delimits the subject under study, as well as standardizing the terms, maintaining linguistic differences of each country, which allows international comparisons, based on reliable and appropriate measures for researches ${ }^{(33)}$.

In the "outcomes" domain present in the MERSQI instrument, it was found that some studies that comprised the sample ${ }^{(23,26)}$ evaluated the development of cognitive knowledge and psychomotor skills and did not choose a more global assessment process, which considers the improvement of affective skills/attitudes of nursing students. 
The affective skill in the teaching and learning process is related to feelings, postures, affective reactions, empathy, confidence and student satisfaction ${ }^{(29)}$. The researches involving the adoption of serious game for learning in nursing has been striving to include, in its evaluations, the affective aspects of students, however, the incipience of validated instruments for this purpose impairs this measurement ${ }^{(29)}$.

It is possible to affirm that, despite the recommendation on the importance of assessing the clinical competences of nursing students and addressing, for this purpose, instruments capable of verifying the improvement of cognitive, psychomotor and affective skills, educators still focus on the memorization of concepts and practical aspects, not requiring more sophisticated games, which contemplate the development of attitudes ${ }^{(1)}$. Finally, it is important to note that no study in the sample of the present study evaluated the change in student behavior and the reach or impact on the intended outcome for patients, even given the premise that the serious game has, among its educational purposes, the enhancement of learning aimed at changing behavior in nursing and, consequently, obtaining better clinical outcomes for patients in practice ${ }^{(34)}$.

\section{$\square$ CONCLUSION}

The serious game proved to be more effective in improving learning results when compared to traditional teaching, configured by expository class, lecture, materials reading and skills training in the laboratory and by the active strategy of teaching clinical simulation. The findings in this systematic review allow adding scientific evidence to support the teaching and learning process in nursing with the adoption of the serious game.

The limitations of this study were the incipience of experimental and quasi-experimental articles, which compared the effectiveness of the serious game with other teaching strategies for learning specifically in nursing and address its evaluation through MERSQI, to compare the identified weaknesses, which it may have presented itself as an obstacle during the discussion of this context; the difficulty to compare the results of the studies that made up the sample, considering the approach of different measurement instruments, and the variety of terminology available for games, since the expression serious game is not a controlled descriptor.

It is expected that studies with serious games that have defined pedagogical strategies and robust methods can be realized for the future practice of students and nursing professionals, with efficacy proven by the quality of the evidence. The evidence scenario explained here, and the effectiveness of the serious game contributes to educators, researchers and nurses who think of building their own innovative teaching resources, teaching through active and attractive strategies and promoting patient safety and care excellence, given the development of cognitive skills and other competences that arises from serious game.

\section{Q REFERENCES}

1. Gorbanev I, Agudelo-Londoño S, González RA, Cortes A, Pomares A, Delgadillo $V$, et al. A systematic review of serious games in medical education: quality of evidence and pedagogical strategy. Med Educ Online. 2018;23(1):1438718. doi: https://doi.org/10.1080/10872981.2018.1438718

2. Oliveira PS, Vieira IB, Gomes RF, Leão HM, Barbosa RR, Sousa JN. 0 processo ensino-aprendizagem no curso de graduação em enfermagem: uma revisão de literatura. REAS. 2019;20 Supl:e490. doi: https://doi.org/10.25248/reas. e490.2019

3. Souza EF, Silva AG, Silva IL. Active methodologies for graduation in nursing: focus on the health care of older adults. Rev Bras Enferm. 2018;71 (suppl 2):9204. doi: https://doi.org/10.1590/0034-7167-2017-0150

4. Mesquita SK, Meneses RM, Ramos DK. Metodologias ativas de ensino/ aprendizagem: dificuldades de docentes de um curso de enfermagem. Trab Educ Saúde. 2016;14(2):473-86. doi: https://doi.org/10.1590/1981-7746-sip00114

5. Foronda CL, Swoboda SM, Henry MN, Kamau E, Sullivan N, Hudson KW. Student preferences and perceptions of learning from vSIM for Nursing ${ }^{T M}$. Nurse Educ Pract. 2018;33:27-32. doi: https://doi.org/10.1016/j.nepr.2018.08.003

6. Williamson KM, Muckle J. Students' perception of technology use in nursing education. Comput Inform Nurs. 2018;36(2):70-6. doi: https://doi. org/10.1097/CIN.0000000000000396

7. Keys E, Luctkar-Flude M, Tyerman J, Sears K, Woo K. Developing a virtual simulation game for nursing resuscitation education. Clin Simul Nurs. 2020;39:51-4. doi: https://doi.org/10.1016/j.ecns.2019.10.009

8. Mobiglia MD, Aredes NDA, Hetzel CS, Monti FLM. Serious Game e-Baby Família: an educational technology for premature infant care. Rev Bras Enferm. 2020;73(4):e20190116. doi: https://doi.org/10.1590/0034-7167-2019-0116

9. Aredes NDA, Dias DMV, Fonseca LMM, Campbell SH, Martins JCA, Rodrigues MA. E-baby skin integrity: evidence-based technology innovation for teaching in neonatal nursing. Esc Anna Nery. 2018;22(3):e20170424. doi: https://doi. org/10.1590/2177-9465-ean-2017-0424

10. Silveira MS, Cogo ALP. The contributions of digital technologies in the teaching of nursing skills: an integrative review. Rev Gaúcha Enferm. 2017;38(2):e66204. doi: https://doi.org/10.1590/1983-1447.2017.02.66204

11. Mueller S, Soriano D, Boscor A, Saville NM, Arjyal A, Baral S, et al. MANTRA: a serious game improving knowledge of maternal and neonatal health and geohazards in Nepal. Eur J Public Health. 2019;29(Suppl 4):ckz185.329. doi: https://doi.org/10.1093/eurpub/ckz185.329

12. Gentry SV, Gauthier A, L'Estrade Ehrstrom B, Wortley D, Lilienthal A, Tudor Car $L$, et al. Serious gaming and gamification education in health professions: systematic review. J Med Internet Res. 2019;21(3):e12994. doi: https://doi. org/10.2196/12994

13. Moher D, Liberati A, Tetzlaff J, Altman DG, PRISMA Group. Preferred reporting items for systematic reviews and meta-analyses: The PRISMA statement. PLOS Medicine. 2009;6(7):e1000097. doi: https://doi.org/10.1371/journal. pmed. 1000097 
14. National Institute for Health Research (UK) [Internet]. York: University of York, Centre for Reviews and Dissemination; (2020 [cited 2020 May 30]. International Prospective Register of Systematic Reviews (PROSPERO) [about 1 screen]. Available from: https://www.crd.york.ac.uk/prospero/\#aboutpage

15. Higgins JP, Thomas J, Chandler J, Cumpston M, Li T, Page MJ, et al, editors. Cochrane Handbook for Systematic Reviews of Interventions [Internet]. Version 6.1. London: Cochrane; 2020 [cited 2020 Jul 3]. Available from: https://training. cochrane.org/handbook

16. Santos CM, Pimenta CA, Nobre MR. The PICO strategy for the research question construction and evidencesearch. RevLatino-Am Enfermagem. 2007;15(3):50811. doi: https://doi.org/10.1590/S0104-11692007000300023

17. Ouzzani M, Hammady H, Fedorowicz Z, Elmagarmid A. Rayyan-a web and mobile app for systematic reviews. Syst Rev. 2016;5:210. doi: https://doi. org/10.1186/s13643-016-0384-4

18. Reed DA, BeckmanTJ, WrightSM, Levine RB, Kern DE, Cook DA. Predictive validity evidence for medical education research study quality instrument scores: quality of submissions to JGIM's Medical Education Special Issue. J Gen Intern Med. 2008;23(7):903-7. doi: https://doi.org/10.1007/s11606-008-0664-3

19. Ursi ES, Galvão CM. Prevenção de lesões de pele no perioperatório: revisão integrativa da literatura. Rev Latino-Am Enfermagem. 2006;14(1):124-31. doi: https://doi.org/10.1590/S0104-11692006000100017

20. Fontaine G, Cossette S, Maheu-Cadotte MA, Mailhot T, Heppell S, Roussy C, et al. Behavior change counseling training programs for nurses and nursing students: a systematic descriptive review. Nurse Educ Today. 2019;82:37-50. doi: https:// doi.org/10.1016/j.nedt.2019.08.007

21. Fonseca LM, Aredes ND, Fernandes AM, Batalha LM, Apóstolo JM, Martins $J C$, et al. Computer and laboratory simulation in the teaching of neonatal nursing: Innovation and impact on learning. Rev Latino-Am Enfermagem. 2016;24:e2808. doi: https://doi.org/10.1590/1518-8345.1005.2808

22. Tan AJ, Lee CC, Lin PY, Cooper S, Lau LS, ChuaWL, et al. Designing and evaluating the effectiveness of a serious game for safe administration of blood transfusion: a randomized controlled trial. Nurse Educ Today. 2017;55:38-44. doi: https:// doi.org/10.1016/j.nedt.2017.04.027

23. Bayram SB, Caliskan N. Effect of a game-based virtual reality phone application on tracheostomy care education for nursing students: a randomized controlled trial. Nurse Educ Today. 2019;79:25-31. doi: https://doi.org/10.1016/j. nedt.2019.05.010
24. Boada I, Rodriguez-Benitez A, Garcia-Gonzalez JM, Olivet J, Carreras V, Sbert M. Using a serious game to complement CPR instruction in a nurse faculty. Comput Methods Programs Biomed. 2015;122(2):282-91. doi: https://doi. org/10.1016/j.cmpb.2015.08.006

25. Aljezawi M, Albashtawy M. Quiz game teaching format versus didactic lectures. Br J Nurs. 2015;24(2):86,88-92. doi: https://doi.org/10.12968/ bjon.2015.24.2.86

26. LeFlore JL, Anderson M, Zielke MA, Nelson KA, Thomas PE, Hardee G, et al. Can a virtual patient trainer teach student nurses how to save lives -- teaching nursing students about pediatric respiratory diseases. Simul Healthc. 2012;7(1):10-7. doi: https://doi.org/10.1097/SIH.0b013e31823652de

27. Haoran G, Bazakidi E, Zary N. Serious games in health professions education: review of trends and learning efficacy. Yearb Med Inform. 2019;28(1):240-8. doi: https://doi.org/10.1055/s-0039-1677904

28. Silva FB, Bax MP. Gamification in online education: proposal for a participatory learning model. Encontros Bibli. 2017;22(50):144-60. doi: https://doi. org/10.5007/1518-2924.2017v22n50p144

29. Costa TK, Machado LS, Valença AM, Moraes RM. Assessment model for education in health, based on games and virtual environments. Rev Tempus, Actas Saúde Colet. 2016;10(2):253-73. doi: https://doi.org/10.18569/tempus. v10i2.1663

30. Sardi L, Idri A, Fernández-Alemán JL. A systematic review of gamification in e-Health. J Biomed Inform. 2017;71:31-48. doi: https://doi.org/10.1016/j. jbi.2017.05.011

31. All A, Nuñez-Castellar EP, Van Looy J. Assessing the effectiveness ofdigital game-based learning: Best practices. Comput Educ. 2016;92-93:90-103. doi: https://doi.org/10.1016/j.compedu.2015.10.007

32. Wang R, DeMaria S Jr, Goldberg A, Katz D. A systematic review of serious games in training health care professionals. Simul Healthc. 2016;11(1):41-51. doi: https://doi.org/10.1097/SIH.0000000000000118

33. Nora CRD, Zoboli E, Vieira MM. Validation by experts: importance in translation and adaptation of instruments. Rev Gaúcha Enferm. 2017;38(3):e64851. doi: https://doi.org/10.1590/1983-1447.2017.03.64851

34. Dias JD, Tibes CM, Fonseca LM, Zem-Mascarenhas SH. Use of serious games for coping with childhood obesity: integrative literature review. Texto Contexto Enferm. 2017;26(1):1-10. doi: https://doi. org/10.1590/0104-07072017003010015 
- Acknowledgments:

To the National Council for Scientific and Technological

Development (Conselho Nacional de Desenvolvimento

Científico e Tecnológico - CNPq).

\section{- Authorship contribution:}

Conceptualization; Formal Analysis; Investigation;

Methodology; Project administration; Resources;

Validation; Visualization; Writing-original draft; Writing-

review \& editing: Kleiton Gonçalves do Nascimento.

Formal Analysis; Investigation; Methodology; Resources;

Validation; Visualization; Writing-original draft; Writing-

review \& editing: Márcia Marques dos Santos Felix;

Maria Beatriz Guimarães Ferreira; Juliana da Silva Garcia

Nascimento; Suzel Regina Ribeiro Chavaglia.

Conceptualization; Formal Analysis; Funding

acquisition; Investigation; Methodology; Project

administration; Resources; Supervision; Validation;

Visualization; Writing-original draft; Writing-review \&

editing: Maria Helena Barbosa.

\section{- Corresponding author:}

Maria Helena Barbosa

E-mail: mhelena331@hotmail.com

\section{Associate editor:}

Carlise Rigon Dalla Nora 